\title{
ANOVA to Compare Three Methods to Track COVID-19 in Nine Countries
}

\section{ANOVA en la comparación de tres métodos para rastrear COVID-19 en nueve países}

\author{
J. J. Juárez-Lucero', A. S. Sánchez-Sánchez'1, R. Díaz-Hernández'1, M. R. Guevara-Villa², L. Altamirano-Robles ${ }^{1}$ \\ Instituto Nacional de Astrofísica Óptica y Electrónica \\ 2Universidad Politécnica de Puebla
}

\begin{abstract}
A new coronavirus denominated first 2019-nCoV and later SARS-CoV-2 was found in Wuhan, China in December of 2019. This paper compares three mathematical methods: nonlinear regression, SIR, and SEIR epidemic models, to track the covid-19 disease in nine countries affected by the SARS-CoV-2 virus, to help epidemiologists to know the disease trajectory, considering initial data in the pandemic, mainly 100 days from the beginning. To evaluate the results obtained with the three methods one-way ANOVA is applied. The average of predicted infected cases with SARS-CoV-2, obtained with the mentioned methods was: for United States of America 1,098,508, followed by Spain with 226,721, Italy with 202,953, France with 183,897 United Kingdom with 182,190, Germany with 159,407, Canada with 58,696, Mexico with 50,366 and Argentina with 4,860 in average. The one-way ANOVA does not show a significant difference among the results of the projected infected cases by SARS-CoV-2, using nonlinear regression, SIR, and SEIR epidemic methods. The above could mean that initially any method can be used to model the pandemic course.
\end{abstract}

KEYWORDS: one-way ANOVA; nonlinear regression; SIR; SEIR; COVID-19 


\section{RESUMEN}

Un nuevo coronavirus denominado primero 2019-nCoV y más tarde SARS-CoV-2 fue encontrado en Wuhan, China en diciembre de 2019. El objetivo de este trabajo es comparar tres métodos matemáticos: regresión no lineal, modelos epidemiológicos SIR y SEIR, para rastrear la enfermedad del COVID-19 en nueve países infectados por el virus SARS-CoV-2, con el propósito de ayudar al epidemiólogo a conocer el curso de la pandemia, considerando principalmente sus primeros 100 días. Para evaluar los resultados obtenidos de la aplicación de los tres métodos, se aplicó ANOVA de una vía. El número promedio de casos infectados con SARS-CoV-2, obtenidos con los tres métodos descritos son: para Estados Unidos 1,098,508, seguido de España con 226,721, Italia con 202,953, Francia con 183,897 Reino Unido con 182,190, Alemania con 159,407, Canadá con 58,696, México con 50,366 y Argentina con 4,860 en promedio. El ANOVA de una vía no muestra diferencias significativas entre los resultados de los casos infectados proyectados por SARS-CoV-2, utilizando la regresión no lineal y los métodos SIR and SEIR. Lo anterior podría señalar que cualquiera de los tres métodos estudiados puede modelar el curso de la pandemia en las condiciones descritas para cada uno.

PALABRAS CLAVE: ANOVA de una vía; regresión no lineal; SIR; SEIR; COVID-19

\section{Corresponding author}

TO: Anabel Socorro Sánchez Sánchez

INSTITUTION: Instituto Nacional de Astrofísica

Óptica y Electrónica

ADDRESS: Luis Enrique Erro \#4, Santa María Tonanzintla,

C. P. 72840, San Andrés Cholula, Puebla, México

E-MAIL: anabel@inaoep.mx

\section{Received:}

20 August 2020

Accepted:

27 November 2020 


\section{INTRODUCTION}

A new coronavirus denominated first 2019-nCoV and later SARS-CoV-2 was found in Wuhan, China in

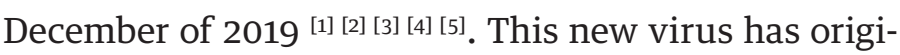
nated a worldwide pandemic ${ }^{[6]}$, worse than the Severe Acute Respiratory Syndrome Coronavirus epidemic (SARS-CoV) and Middle Eastern Respiratory Syndrome Coronavirus (MERS-CoV) epidemic [7] [8] [9]. It is believed that SARS-CoV-2 jump from the bats to humans, the bats were on the markets and restaurants in Southern China with the potential to cause a global outbreak ${ }^{[10]}$. The World Health Organization (WHO) called it COVID19 disease.

Lin et al. propose in 2020 a conceptual model to control the COVID-19 outbreak. The model includes among other measurements: holiday extension, travel restriction, hospitalization, and quarantine of the population [11]. Additionally, computational advances in the performance of algorithms may help epidemiologists to take decisions in case of outbreaks ${ }^{[12]}$.

Currently, exist mathematical models to predict or simulate an epidemic spread among them: Nonlinear regression ${ }^{[13]}$, SIR ${ }^{[14]}$, SEIR ${ }^{[15]}$. Other methods exist that use more variables, but they can be used when the pandemic has already produced enough data it means no at the beginning of the pandemic outbreak.

The Nonlineal model has been used to estimate the impact of the COVID-19 from a global perspective in Germany ${ }^{[13]}$.

The effectiveness of modeling the COVID-19 pandemic with the SIR model was evaluated in 6 countries [14]. And the SEIR epidemic model was employed to build some general control strategies ${ }^{[15]}$. These three models were chosen because they consider variables that can be known during the epidemic beginning, making it possible to calculate the prediction of the infected people in any country.
The SIR model analyses different variables like the number of people susceptible to sickness, $\mathrm{S}(\mathrm{t})$, the number of infected persons, I(t), and the removed people free of spread infection or recovered people, $R(t){ }^{[16][17]}$.

The SEIR model uses the same $\mathrm{S}(\mathrm{t})$, and $\mathrm{R}(\mathrm{t})$, variables adding the exposed time to the disease, $\mathrm{E}(\mathrm{t})$, and then studies the effect of infected persons $I(t)$ overexposed people like a new parameter [12] [16] [18] [19] [20] [21]. Meanwhile, if the model includes immunization and population quarantine, $\mathrm{Q}(\mathrm{t})$, and isolation, $\mathrm{J}(\mathrm{t})$, the SEQIJR model is used ${ }^{[14]}{ }^{[22]}$.

Thus, the aim of this paper to find the first approximation to help epidemiologist taking decisions about pandemic management, mainly at the beginning by comparing three mathematical methods (nonlinear regression, SIR, and SEIR epidemic simulations) used to track the COVID-19 disease in nine representatives countries (Argentina, Canada, France, Germany, Italy, Mexico, Spain, United Kingdom and the United States of America) affected by SARS-CoV-2 virus applying one-way ANOVA.

The nonlinear method was employed as a first statistics approximation and the SIR and SEIR models are based on differential equations solutions taken in account the infected, recovery, susceptible, and dead people.

\section{MATERIALS AND METHODS}

Tree mathematical models are applied to simulate COVID-19 disease: Nonlinear regression, SIR, and SEIR. These are described below. Two programs were used from GitHub of MathWorks.

\section{Nonlinear regression model}

The nonlinear regression method to obtain the A, B, and $\mathrm{C}$ to solve the equation (1), was modeled with Coronavirus Tracker-Country Modeling, available at https://rb.gy/pbwexu. 


$$
y \sim \frac{A}{\left(1+C * e^{-B x}\right)}
$$

\section{SIR Model}

The SIR model also called Kermack and McKendrick's model was evaluated using the function fitVirusCV19v3 (COVID-19 SIR Model) from the MathWorks webpage at https://rb.gy/qblldl. This method has three variables or parameters: susceptible (S), infected (I), and recovered $(\mathrm{R}){ }^{[14]} . \mathrm{N}$ is the variable that represents the number of total populations in the $\mathrm{S}(\mathrm{t}), \mathrm{I}(\mathrm{t})$, and $\mathrm{R}(\mathrm{t})$ functions. This model can be solved by ordinary differential equations solutions with the initial conditions $\mathrm{S}(0)=\mathrm{S} 0>0, \mathrm{I}(0)=\mathrm{I} 0>0, \mathrm{R}(0)=\mathrm{R} 0>0$. Figure 1 shows the epidemic flow diagram and the equations of the model in (2), (3), (4).

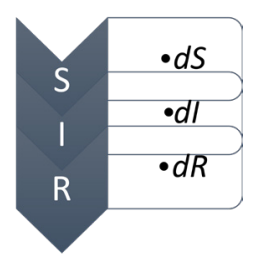

FIGURE 1. Diagram of SIR model following the solutions of the differential equations to find the solution.

$$
\begin{gathered}
\frac{d S}{d t}=\frac{-\beta}{N} I S \\
\frac{d I}{d t}=\frac{\beta}{N} I S-\gamma I \\
\frac{d R}{d t}=\gamma I
\end{gathered}
$$

$\mathrm{S}(\mathrm{t})$ is the susceptible, $\mathrm{I}(\mathrm{t})$ the infected, and $\mathrm{R}(\mathrm{t})$ the recovered people at the time $\mathrm{t}$. $\beta$ is the constant that represents the contact rate and $\gamma$ is the inverse of the average infectious period. $\mathrm{N}$ is the total population in the function of the other variables

$$
N=S(t)+I(t)+R(t)
$$

\section{SEIR Model}

The SEIR method was modeled with the Epidemic Calculator program obtained from $h t t p s: / / r b . g y / 4 q g u a n$. The SEIR model can analyse infectious diseases where the people have an exposed period to the virus and can transmit the infection to the rest of the population. The epidemic SEIR model diagram is shown in Figure 2 and its equations in (6), (7), (8), (9).

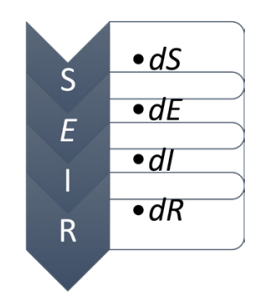

FIGURE 2. Diagram of the SEIR model following the solution of the differential equations to find the solution.

$$
\begin{gathered}
\frac{d S}{d t}=-\beta I S \\
\frac{d E}{d t}=\frac{\beta}{N} I S-k E
\end{gathered}
$$

$\mathrm{S}, \mathrm{I}$, and $\mathrm{R}$ are the same values of susceptible, $\mathrm{S}(\mathrm{t})$, infected, $\mathrm{I}(\mathrm{t})$, and recovery, $\mathrm{R}(\mathrm{t})$, people respectively with exposed $\mathrm{E}(\mathrm{t})$ in the function of time.

The exposed people E(t) into the SEIR model is constituted by two classes, the first one is related to people that do not have the infection yet, and the second is the persons that change to recovered status. The new population number is:

$$
N=S(t)+E(t)+I(t)+R(t)
$$



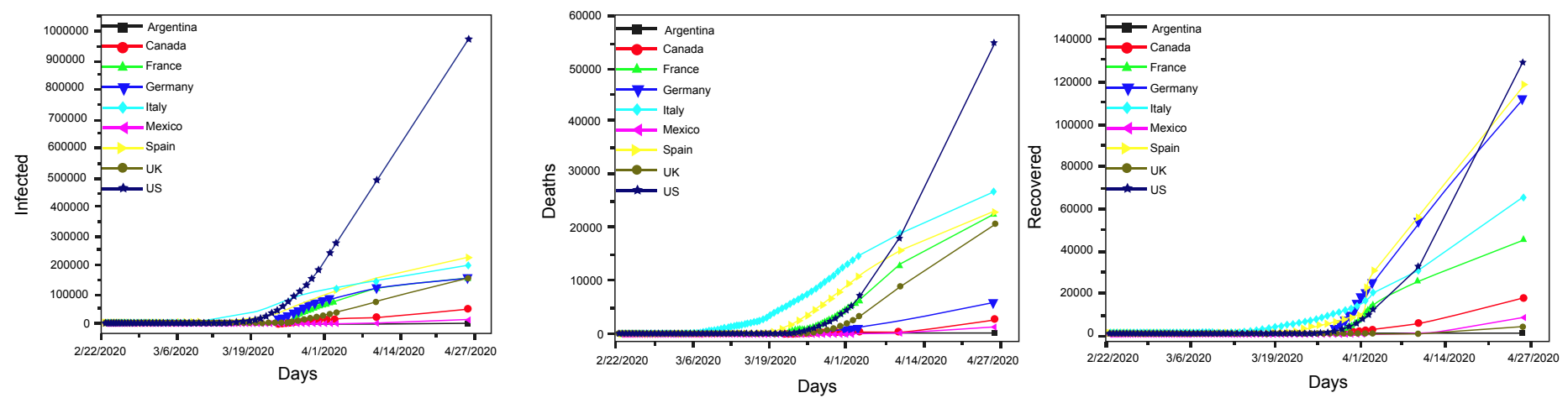

FIGURE 3. Representation of the real number of a) infected, b) deaths, and c) recovered people with the COVID-19 infection from the beginning of the SARS-CoV-2 virus propagation until 4/27/2020 of nine countries in this research.

\section{RESULTS AND DISCUSSION}

The nine countries were chosen as a representation from Europe of those where a decrease of SARS-CoV-2 infection was identified. The disease in the early stages in the American continent was evaluated in four of the bigger countries to compare with the European countries. Brazil was discarded because the model SIR cannot be calculated for having many infections peaks. Figure 3 shows the number of real infected, death, and recovered people of COVID-19 disease obtained from https://data.humdata.org and https://covid19info.live/. These data show that the epidemic is growing, the US has the greatest number of infected people of the nine countries studied followed by Spain, Italy, France, United Kingdom, Germany, Canada, Mexico, and Argentina as shown in figure 3.

In this period Argentina is the country with less infected people. However, the US occupies first place in recovered people followed by Spain, Germany, Italy, France, Canada, Mexico, UK, and Argentina. In the European countries, the disease exists since a few weeks ago and it is just beginning in Latin America. Most deaths were in the US followed by Italy, Spain, France, UK, Germany, Canada, Mexico, and Argentina. To study the propagation of the disease in the countries, one first statistics approximation to predict the maximum of infected cases of COVID-19 disease was realized with the coronavirus tracker, country model- ing version 2.6.7 by Joshua McGee from MathWorks. This function was used to evaluate all the variables needed to solve the equations and calculate the values of the A, B, C variables of the equation (1) with the real data obtained from https://data.humdata.org of the nine countries studied. The simulation is shown in Figure 4, and the values of the constants A, B, C, and the solutions of the total cases predicted with this model are described in Table 1 . The US has a major number of infected people with $1,098,508$ sick persons. Argentina on the other hand shows the less sick people with 4,860 predicted confirmed cases.

TABLE 1. Confirmed total cases obtained solving the nonlinear equation 1.

\begin{tabular}{|c|c|c|c|c|}
\hline \multicolumn{5}{|c|}{ Nonlinear regression simulation } \\
\hline Country & A & B & C & $\begin{array}{c}\text { Confirmed } \\
\text { Total Cases }\end{array}$ \\
\hline Argentina & $4,506.9$ & 0.11097 & 30.922 & 4,504 \\
\hline Canada & 55,765 & 0.12697 & 56.777 & 55,755 \\
\hline France & $1.8275 \mathrm{e} 5$ & 0.13328 & 181.43 & 182,696 \\
\hline Germany & $1.5488 \mathrm{e} 5$ & 0.15681 & 133.67 & 154,876 \\
\hline Italy & $1.9566 \mathrm{e} 5$ & 0.11976 & 75.568 & 195,566 \\
\hline Mexico & 44,292 & 0.10814 & 170.35 & 44,140 \\
\hline Spain & $2.1922 \mathrm{e} 5$ & 0.14474 & 54.74 & 219,213 \\
\hline $\begin{array}{c}\text { United } \\
\text { Kingdom }\end{array}$ & $1.7088 \mathrm{e} 5$ & 0.14075 & 252.4 & 170,846 \\
\hline $\begin{array}{c}\text { United } \\
\text { States }\end{array}$ & $1.0527 \mathrm{e} 6$ & 0.1384 & 132.43 & $1.05256 \mathrm{E} 6$ \\
\hline
\end{tabular}

'https://la.mathworks.com/matlabcentral/fileexchange/74557coronavirus-tracker-country-modeling?s tid=srchtitle 

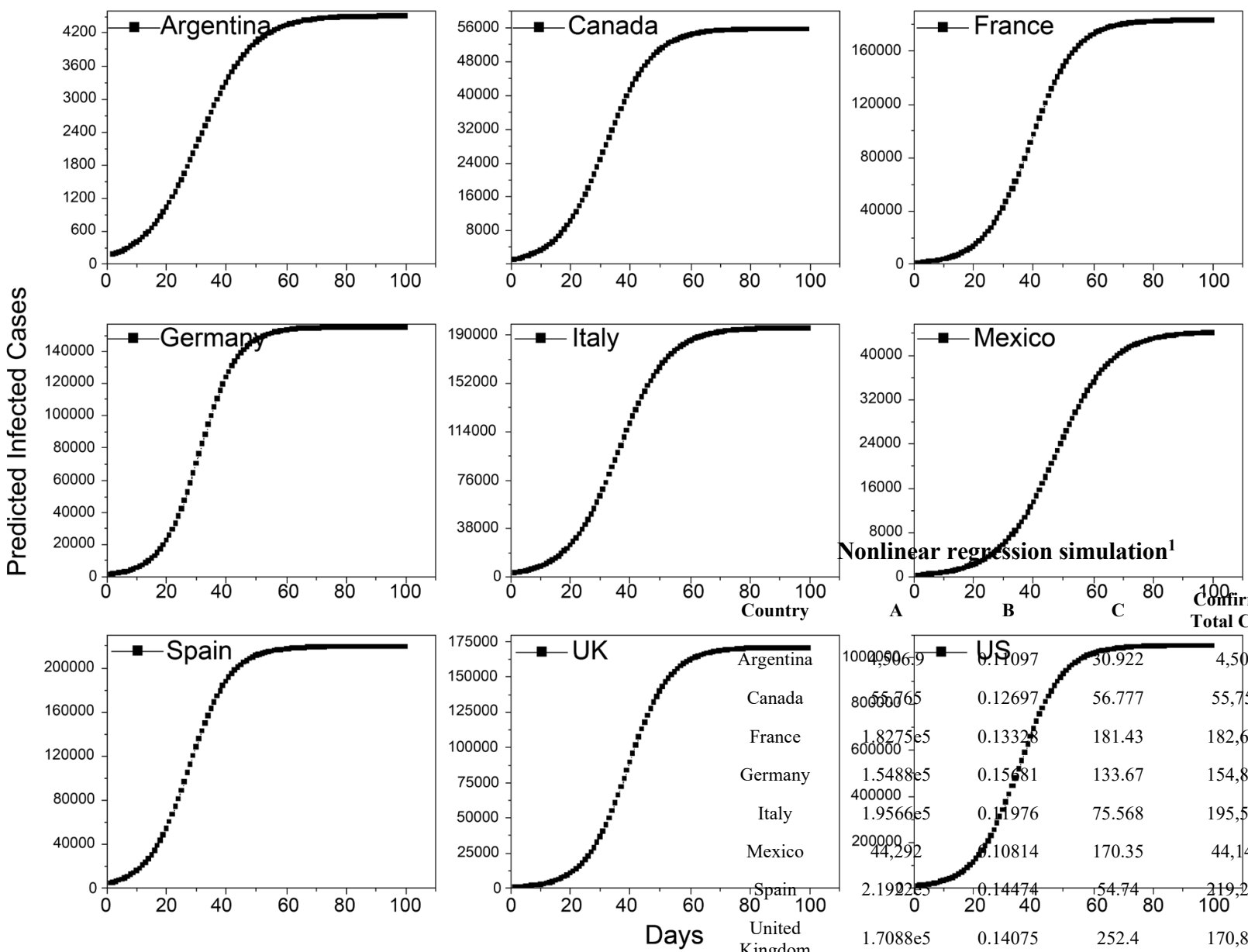

FIGURE 4. The predicted infected cases of SARS-CoV-2 using the nonlinear modelling in Argentina, Canada, France, Germany, Italy, Mexico, Spain, UK and US.

Table 2 shows the projected deaths in the nine countries using the nonlinear regression model. For the US the model predicts the most quantity of deaths with 59,929 followed by Italy with 26,373 , France with 25,790, the UK with 23,067, Spain with 22,432, Germany with 5,866, Mexico with 4,077, Canada with 3,148 and for Argentina the model predicts the smallest value with 222 .

Results using the SIR epidemic model program downloaded from MathWorks are shown in Figure 5 for each country. The total of daily predicted cases with this model are adjusted for Canada, France, Germany, Italy, Mexico, and the UK, but not for Argentina, Spain, and the US. This model shows that Argentina, Canada,
TABLE 2. Projected deaths using the nonlinear regression simulation.

\begin{tabular}{|c|c|}
\hline \multicolumn{2}{|c|}{ Nonlinear regression simulation ${ }^{\mathbf{1}}$} \\
\hline Country & Projected Deaths $^{2}$ \\
\hline Argentina & 3,148 \\
\hline Canada & 25,790 \\
\hline France & 5,866 \\
\hline Germany & 26,373 \\
\hline Italy & 4,077 \\
\hline Mexico & 22,432 \\
\hline Spain & 23,067 \\
\hline United Kingdom & 59,929 \\
\hline United States & \\
\hline
\end{tabular}

'https://la.mathworks.com/matlabcentral/fileexchange/74557coronavirus-tracker-country-modeling?s tid=srchtitle 

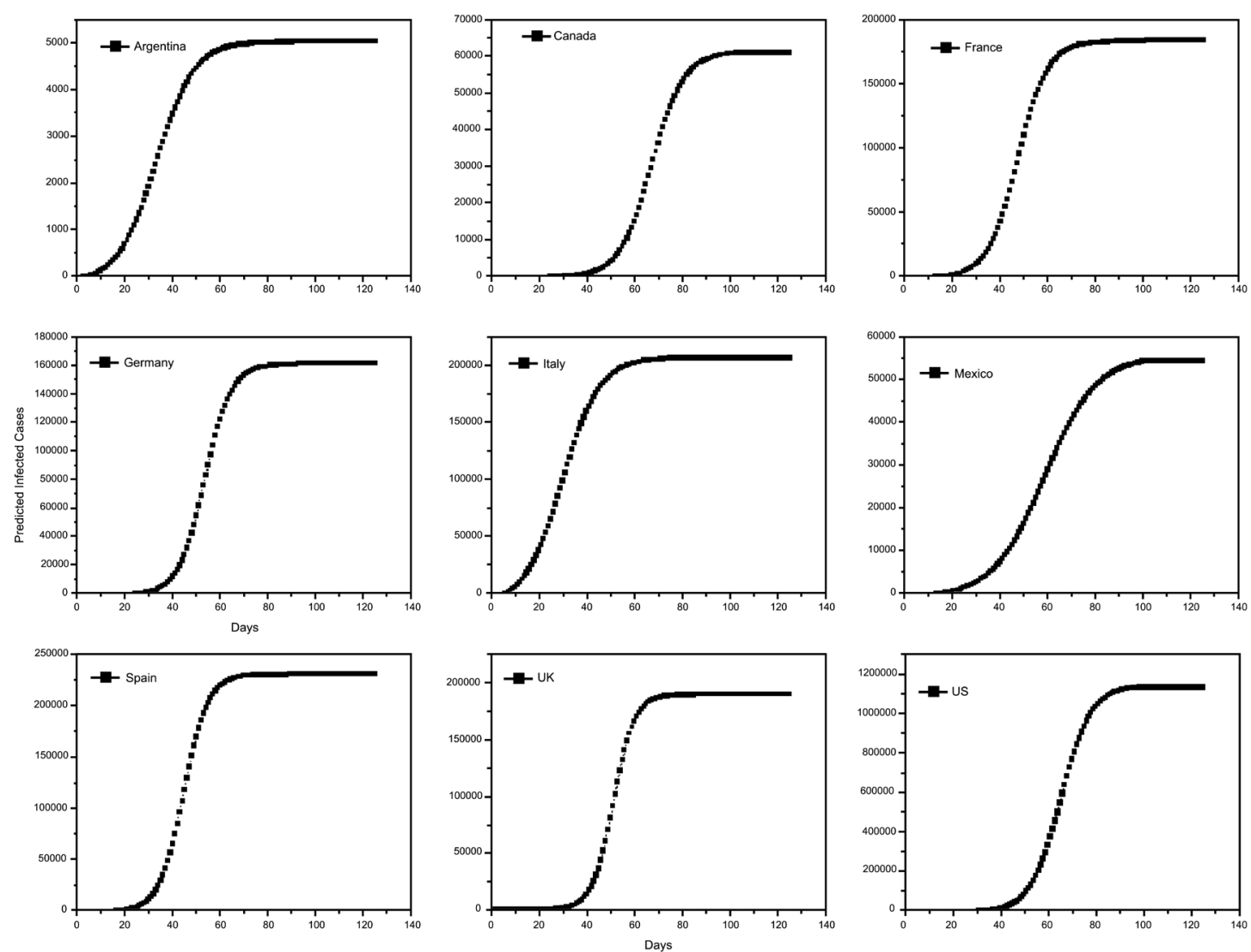

FIGURE 5. The predicted infected cases of SARS-CoV-2 using the SIR epidemic model using fitVirusCV19v3 (COVID-19 SIR Model) by Joshua McGee from MathWorks in a) Argentina, b) Canada, c) France, d) Germany, e) Italy, f) Mexico, g) Spain, h) the UK and i) the US.

France, Germany, Italy, Spain, UK, and the US are decreasing in the number of total daily cases while France, Germany, Italy, and Spain are near to the final cases predicted. Mexico is the only one that is growing the disease. The tendency of cases predicted is near to close in the countries where the COVID-19 started such as France, Germany, Italy, and Spain.

The fitviruscv19v3-covid-19-sir-model function (from MathWorks page, https://rb.gy/qblldl) was also used to calculate the values of the contact rate $\beta$, the inverse of the average infectious period $\gamma$ and the basic reproduction number Ro, required to predict the total projected confirmed cases of COVID-19 and these data were used to evaluate both epidemic models (SIR and SEIR). The data obtained from the software are shown in table 3.
TABLE 3. SIR epidemic model simulation values'.

\begin{tabular}{|c|c|c|c|c|c|c|}
\hline \multicolumn{7}{|c|}{ SIR epidemic model simulation } \\
\hline Country & $\begin{array}{c}\% \\
\text { Deaths }^{2}\end{array}$ & $\begin{array}{c}\% \\
\text { Infected }^{2}\end{array}$ & $\boldsymbol{\beta}$ & $\gamma$ & Ro $^{\mathbf{1}}$ & Pop $^{\mathbf{3}}$ \\
\hline Argentina & 4.9 & 66.6 & 0.641 & 0.541 & 1.182 & $44 \mathrm{e} 6$ \\
\hline Canada & 5.7 & 57.5 & 0.298 & 0.166 & 1.792 & $37 \mathrm{e} 6$ \\
\hline France & 14 & 58.1 & 1.849 & 1.714 & 1.079 & $66 \mathrm{e} 6$ \\
\hline Germany & 3.9 & 24 & 0.307 & 0.136 & 2.25 & $83 \mathrm{e} 6$ \\
\hline $\begin{array}{c}\text { Italy } \\
\text { Mexico }\end{array}$ & 13.5 & 53.1 & 0.26 & 0.135 & 1.928 & $60 \mathrm{e} 6$ \\
\hline Spain & 10 & 32.3 & 0.239 & 0.132 & 1.81 & $129 \mathrm{e} 6$ \\
\hline $\begin{array}{c}\text { United } \\
\text { Kingdom }\end{array}$ & 13.3 & 83.9 & 0.303 & 0.16 & 1.896 & $66 \mathrm{e} 6$ \\
\hline $\begin{array}{c}\text { United } \\
\text { States }\end{array}$ & 5.7 & 80.5 & 0.313 & 0.167 & 1.868 & $327 \mathrm{e} 6$ \\
\hline
\end{tabular}

'https://la.mathworks.com/matlabcentral/fileexchange/74676fitviruscv19v3-covid-19-sir-model ${ }^{2}$ https://covid19info.live

${ }^{3}$ https://www.google.com 
(a)

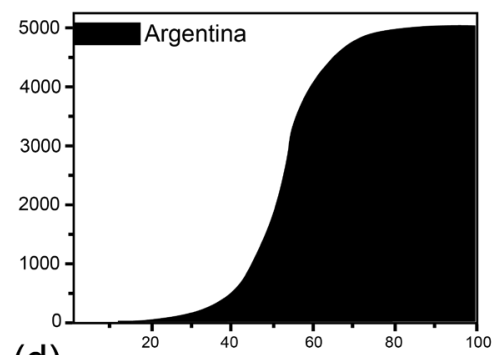

(d)

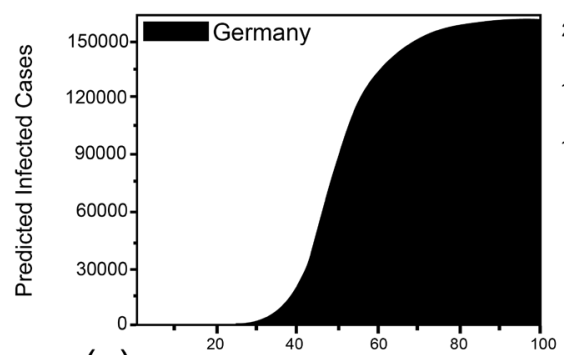

(g)

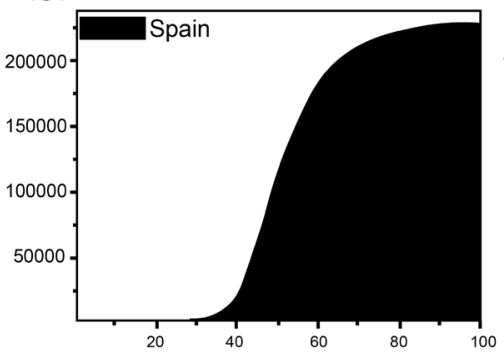

(b)

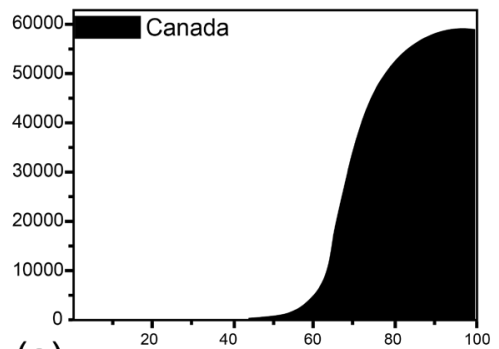

(e)

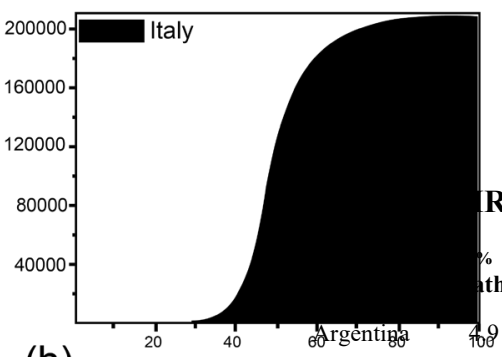

(h)

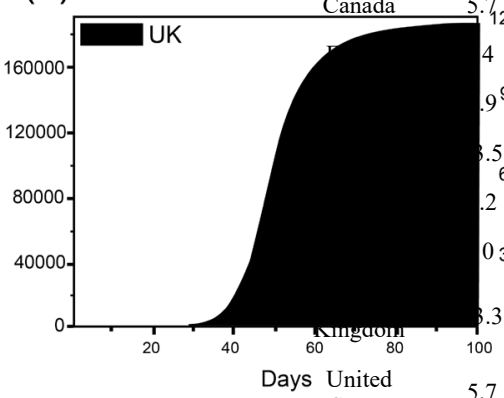

(c)

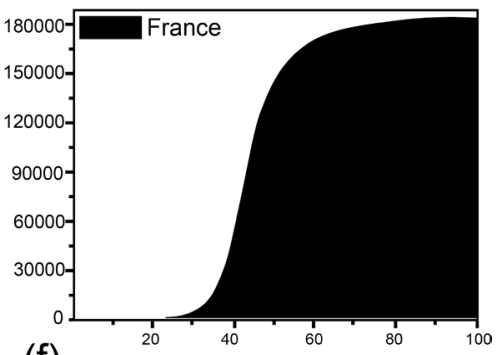

(f)

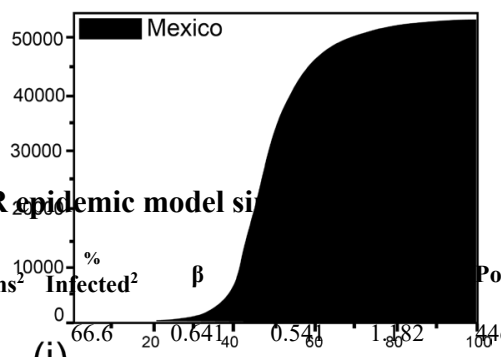

(i)

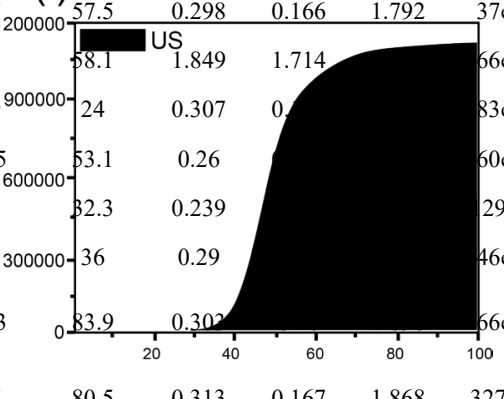

FIGURE 6. The predicted infected cases of SARS-CoV-2 using the SEIR epidemic calculator from the beginning of the COVID-19 infection until 4/27/2020 in a) Argentina, b) Canada,

c) France, d) Germany, e) Italy, f) Mexico, g) Spain, h) the UK and i) the US.

The data obtained for $\beta$, $\gamma$ and Ro with the SIR model were used in the simulator of SEIR epidemic model in http://gabgoh.github.io/COVID/index.html to obtain the graphs of Figure 6 to predict the projected infected cases in Argentina, Canada, France, Germany, Italy, Mexico, Spain, UK, and the US. Table 4 shows the data of the variables obtained with the SEIR epidemic model to make the predictions.

Table 4 shows values of the contact rate $\beta$, the mean exposed period $1 / \kappa$, the rate at a recovery of disease $\gamma=1 / \alpha$, where $\alpha$ represents the infectious period, and basic reproduction number Ro calculated with the SEIR model in the epidemic calculator modeling obtained in http://gabgoh.github.io/COVID/index.html.
TABLE 4. SEIR epidemic model simulation'.

\begin{tabular}{|c|c|c|c|c|c|}
\hline \multicolumn{7}{|c|}{ SEIR epidemic model simulation ${ }^{1}$} \\
\hline Country & Population & Ro & B & $\boldsymbol{\kappa}$ & $\boldsymbol{\alpha}$ \\
\hline Argentina & $44 \mathrm{e} 6$ & 1.182 & 0.22 & 2.5 & 0.44 \\
\hline Canada & $37 \mathrm{e} 6$ & 1.792 & 0.21 & 0.21 & 0.43 \\
\hline France & $66 \mathrm{e} 6$ & 1.079 & 0.86 & 6.25 & 1.72 \\
\hline Germany & $83 \mathrm{e} 6$ & 2.25 & 0.15 & 0.17 & 0.29 \\
\hline Italy & $60 \mathrm{e} 6$ & 1.928 & 0.14 & 0.28 & 0.29 \\
\hline Mexico & $129 \mathrm{e} 6$ & 1.81 & 0.10 & 0.45 & 0.20 \\
\hline Spain & $46 \mathrm{e} 6$ & 2.18 & 0.11 & 0.25 & 0.22 \\
\hline $\begin{array}{c}\text { United } \\
\text { Kingdom }\end{array}$ & $66 \mathrm{e} 6$ & 1.896 & 0.11 & 0.41 & 0.22 \\
\hline $\begin{array}{c}\text { United } \\
\text { States }\end{array}$ & $327 \mathrm{e} 6$ & 1.868 & 0.14 & 0.43 & 0.29 \\
\hline
\end{tabular}

Ihttp://gabgoh.github.io/COVID/index.html 
Table 5 shows the results predicted using the three models: the nonlinear regression, the SIR and SEIR epidemic model, and the average of the total projected confirmed cases of COVID-19 in the nine studied countries.

TABLE 5. The total confirmed cases of COVID-19 in the nine countries studied.

\begin{tabular}{|c|c|c|c|c|}
\hline \multicolumn{5}{|c|}{ Total Projected Confirmed Cases } \\
\hline Country & $\begin{array}{c}\text { Nonlinear } \\
\text { regression } \\
\text { simulation }\end{array}$ & $\begin{array}{c}\text { SIR } \\
\text { epidemic } \\
\text { model } \\
\text { simulation }\end{array}$ & $\begin{array}{c}\text { SEIR } \\
\text { epidemic } \\
\text { model } \\
\text { simulation }\end{array}$ & Average \\
\hline Argentina & 4,504 & 5,000 & 5,076 & 4,860 \\
\hline Canada & 55,755 & 60,053 & 60,280 & 58,696 \\
\hline France & 182,696 & 184,286 & 184,711 & 183,897 \\
\hline Germany & 154,876 & 161,426 & 161,921 & 159,407 \\
\hline Italy & 195,566 & 205,483 & 207,812 & 202,953 \\
\hline Mexico & 44,140 & 53,462 & 53,496 & 50,366 \\
\hline Spain & 219,213 & 229,050 & 231,901 & 226,721 \\
\hline $\begin{array}{c}\text { United } \\
\text { Kingdom }\end{array}$ & 170,846 & 187,819 & 187,905 & 182,190 \\
\hline $\begin{array}{c}\text { United } \\
\text { States }\end{array}$ & $1.05256 \mathrm{E} 6$ & $1.12119 \mathrm{e} 6$ & $1,121,774$ & $1,098,508$ \\
\hline
\end{tabular}

In figure 7 data are plotted and show that United States has the greatest average number of cases with 1,098,508 followed by Spain with 226,721, Italy with 202,953, France with 183,897 United Kingdom with 182,190 , Germany with 159,407, Canada with 58,696, Mexico with 50,366, and Argentina with 4,860 in average.

Like the number of infected people in different countries is not equivalent, the comparison between the three methods is not balanced, besides to find if the methods have a significant difference around the means of nonlinear regression, SIR and SEIR method one-way ANOVA is used to compare them.

One-way ANOVA study is showed in Table 6. As can be seen from the data the three methods mean are not significantly different.

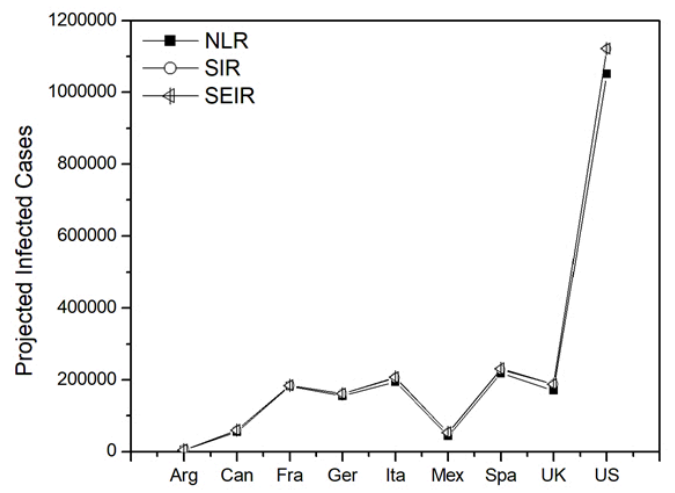

FIGURE 7. Comparison of projected infected cases between the three models studied: nonlinear regression, SIR and SEIR epidemic model of the COVID-19 infection from the beginning of the SARS-CoV-2 virus propagation until 4/27/2020 of nine countries.

Other studies have modeled SARS-COV 2, applying different models including nonlinear regression, SIR, and SEIR epidemic models [7] [11] [12] [13] [14] [15] [18] [19] [20], but they have no compared the results obtained among them as it is done in this paper.

TABLE 6. One-way ANOVA' ${ }^{1}$ of the nonlinear regression, SIR, and SEIR epidemic model.

\begin{tabular}{|c|c|c|c|}
\hline \multicolumn{4}{|c|}{ One-way ANOVA } \\
\hline Data & Mean & Variance & N \\
\hline NLR & $231,128.44$ & $1.00629 \mathrm{E} 11$ & 9 \\
\hline SIR & $245,307.66$ & $1.13995 \mathrm{E} 11$ & 9 \\
\hline SEIR & $246,097.33$ & $1.14054 \mathrm{E} 11$ & 9 \\
\hline \multicolumn{4}{|c|}{$\mathrm{F}=0.00583$} \\
\hline \multicolumn{4}{|c|}{$\mathrm{P}=0.99419$} \\
\hline
\end{tabular}

Thus, if the results obtained are considered with the SIR model, then it can be observed that the REAL cases fit very well with the SIMULATED ones. When the SEIR model simulation is carried out, there are no variations, since there is no effect to take into account "for this virus" with the asymptomatic people who were exposed, E (t), since they do not generate significant variations for the model. Then the two models present 
similar results, which is what is being obtained in the one-way ANOVA. Therefore, it could be said from this comparison, that the SIR model is sufficient to predict the rest of the pandemic. Additionally, it is possible to see that for the SEIR model, there is a little effect when asymptomatic exposed people to this virus are taken into account, it can be assumed that there is no effect because they are only infecting the others, and since they do not present symptoms, the SEIR model considers them healthy until they are already part of the group of infected, I (t), so the results are similar.

On the other hand, the linear regression model is only making an adjustment with the real data and only allows predicting the maximum value of possible cases of infected people, but the SIR model can predict the daily cases and their decrease per day and predict how long the infection period can last.

\section{CONCLUSIONS}

The nine countries studied concerning the projected infected cases by SARS-CoV-2 using nonlinear regression method, SIR and SEIR epidemic model simulation, do no show equal predicted values, but those are not statistically different. It is confirmed by one-way ANOVA analysis. The above could mean that initially any method can be used to model the pandemic course.

These methods can be a first approximation and could help health professionals, not only the epidemiologist, to make decisions with a general point of view of a pandemic evolution.

\section{AUTHOR CONTRIBUTIONS}

J.J.J.L. Carried out the analysis, performed calculations for the models and code execution and the ANOVA analysis. Writing the manuscript. A.S.S.S. Conceived the study and wrote the manuscript. Prepared the figures and tables, performed the ANOVA analysis, and carried out conclusions. R.D.H. Caried out analysis and evaluation, performed code execution and calculations for Nonlinear model. M.R.G.G.V. Carried out analysis and evaluation, performed code execution and calculations for SEIR model. L.A.R. Carried out graphics distribution and performed experiments. Supervised writing of manuscript. 


\section{REFERENCES}

[1] Phan T. Novel coronavirus: From discovery to clinical diagnostics. Infect Gen Evol [Internet]. 2020;79:104210-104211. Available from: https://doi.org/10.1016/j.meegid.2020.104211

[2] Xie M, Chen Q. Insight into 2019 novel coronavirus - an updated intrim review and lessons from SARS-CoV and MERS-CoV. Int J Infect Dis [Internet]. 2020;94:119-124. Available from: https://doi.org/10.1016/j.ijid.2020.03.071

[3] Lupia T, Scabini S, Mornese-Pinna S, Di-Perri G, Giuseppe-De-Rosa F, Corcione S. 2019 novel coronavirus (2019-nCoV) outbreak: A new challenge. J Global Antimicrob Resist. [Internet] 2020;21:22-27. Available from: https://doi.org/10.1016/j.jgar.2020.02.021

[4] Shereen MA, Khan S, Kazmi A, Bashir N, Siddique R. COVID-19 infection: Origin, transmission, and characteristics of human coronaviruses. J Adv Res [Internet]. 2020;24:91-98. Available from: https://doi.org/10.1016/i.jare.2020.03.005

[5] Ghinai I, McPherson TD, Hunter JC, Kirking HL, Christiansen D, Joshi K, et al. First known person-to-person transmission of severe acute respiratory syndrome coronavirus 2 (SARS-CoV-2) in the US. The Lancet [Internet]. 2020;395(10230):1137-1144. Available from: https://doi.org/10.1016/S0140-6736(20)30607-3

[6] Lai CC, Shih TP, Ko WC, Tang HJ, Hsueh PR. Severe acute respiratory syndrome coronavirus 2 (SARS-CoV-2) and coronavirus disease-2019 (COVID-19): The epidemic and the challenges. Int J Antimicrob Agents [Internet]. 2020;55(3):105924. Available from: https://doi.org/10.1016/j.ijantimicag.2020.105924

[7] Luk HKH, Li X, Fung J, Lau SPK, Woo PCY. Molecular epidemiology, evolution, and phylogeny of SARS coronavirus. Infect Genet Evol [Internet]. 2019;71(Jul):21-30. Available from: https://doi.org/10.1016/j.meegid.2019.03.001

[8] Ramadan N, Shaib H. Middle East respiratory syndrome coronavirus (MERS-CoV): A review. Germs [Internet]. 2019;9(1):3542. Available from: https://dx.doi.org/10.18683\%2Fgerms.2019.1155

[9] Law S, Leung AW, Xu C. Severe Acute Respiratory Syndrome (SARS) and Coronavirus disease-2019 (COVID-19): From Causes to Preventions in Hong Kong. Int J Infect Dis [Internet]. 2020;94:156163. Available from: https://doi.org/10.1016/j.ijid.2020.03.059

[10] Wong ACP, Li X, Lau SKP, Woo PC. Global Epidemiology of Bat Coronaviruses. Viruses [Internet]. 2019; 11(2):174. Available from: https://doi.org/10.3390/v11020174

[11] Lin Q, Zhao S, Gao D, Lou Y, Yang S, Musa SS, He D. A conceptual model for the coronavirus disease 2019 (COVID-19) outbreak in Wuhan, China with individual reaction and governmental action. Int J Infect Dis [Internet]. 2020; 93:211-216. Available from: https://doi.org/10.1016/j.ijid.2020.02.058

[12] Shatnawi M, Lazarova-Molnar S, Zaki N. Modeling and simulation of epidemic spread: Recent advances. In: 9th International Conference on Innovations in Information Technology (IIT) [Internet]. Abu Dhabi: IEEE; 2013:118-123. Available from: https://doi.org/10.1109/Innovations.2013.6544404
[13] Ershkov SV, Christianto V, Rachinskaya A., Prosviryakov EY. A nonlinear heuristic model for estimation of Covid-19 impact to world. Roma Rep Phys [Internet]. 2020;72:1-16. Available from: http://www.rrp.infim.ro/2020/AN72605.pdf

[14] Cooper I, Mondal A, Antonopoulos CG. A SIR model assumption for the spread of COVID-19 in different communities. Chaos Soliton Fract [Internet]. 2020; 139:110057. Available form: https://doi.org/10.1016/j.chaos.2020.110057

[15] He S, Peng Y, Sun K. SEIR modeling of the COVID-19 and its dynamics. Nonlinear Dyn [Internet]. 2020; 101:1667-1680. Available from: https://doi.org/10.1007/s11071-020-05743-y

[16] Brauer F, Castillo-Chávez C. Discrete population models. In: Mathematical models in population biology and epidemiology [Internet]. New York: Springer; 2001. 51-94p. Available from: https://doi.org/10.1007/978-1-4757-3516-1_2

[17] Agrawal A, Tenguria A, Modi G. MATLAB Programming for Simulation of an SIR Deterministic Epidemic Model. IJMTT [Internet]. 2017;50(1):71-73. Available from: https://doi.org/10.14445/22315373/IJMTT-V50P509

[18] Al-Sheikh SA. Modeling and Analysis of an SEIR Epidemic Model with a Limited Resource for Treatment. GJSFR Mathematics and Decision Sciences [Internet]. 2012; 12(14):56-66. Available from: https://globaljournals.org/GJSFR_Volume12/5-Modeling-andAnalysis-of-an-SEIR-Epidemic.pdf

[19] Agrawal A, Tenguria A, Modi G. Global analysis of an SEIRS epidemic model with saturated incidence and saturated treatment. AJOMCOR [Internet]. 2017;22(2):43-56. Available from: $h t t p s: / / ~$ www.ikprress.org/index.php/AJOMCOR/article/view/1150

[20] Yan P, Liu S. SEIR epidemic model with delay. ANZIAM J [Internet]. 2006;48(1):119-134. Available from: https://doi.org/10.1017/S144618110000345X

[21] Stehlé J, Voirin N, Barrat A, Cattuto C, Colizza V, Isella L, Vanhems P. Simulation of an SEIR infectious disease model on the dynamic contact network of conference attendees. BMC Med [Internet]. 2011;9:87. Available from: https://doi.org/10.1186/1741-7015-9-87

[22] Siriprapaiwan S, Moore EJ, Koonprasert S. Generalized reproduction numbers, sensitivity analysis and critical immunity levels of an SEQIJR disease model with immunization and varying total population size. Math Comput Simul [Internet]. 2018;146:7089. Available from: https://doi.org/10.1016/j.matcom.2017.10.006

[23] McGee J. MathWorks. Coronavirus Tracker - Country Modeling [Internet]. 2020; Available from: https://github.com/joshmcgee24/ coronavirustracker 